\title{
Poesía
}

\section{¿Aplaudir o llorar?}

\section{María Soledad Pastor Palomo}

DOI: https://doi.org/10.37536/RIECS.2020.5.2.238

Relato ganador del I Concurso de relato corto "Cuentos confiTados. Cuentos con Corona" del colectivo PAS

¿Dónde está el que nos defiende? Dónde está mirando,

Le están avisando, que viene ya, se acerca por la ciudad de al lado,

Entra por el pueblo vecino,

Ha llegado...

¿Dónde están tus tanques?, tus ametralladoras,

No, ahora no tienes que atacar,

Tienes que defenderme.

No quiero tanques, quiero respiradores,

No quiero rifles, quiero mascarillas,

¡Tengo pólvora!, no quiero,

Necesito gafas protectoras.

Tú, que tendrías que haberme defendido, ¿en qué pensabas?

El enemigo avanza sin tropiezo, pero tú, ¡cuánto has tropezado!

Tanques guardados, pero aquí sin respiradores,

Fusiles calibrados, pero aquí sin lo necesario.

¡me has olvidado!

¡qué solo me has dejado! Así y todo, he luchado,

He trabajado hasta la extenuación...

Corrí el riesgo y conmigo lo llevé hasta mi casa,

Enfermó mi ser querido y murió al que yo amaba,

No me defendiste bien, no.

No puedo salir al balcón,

Aplaudir no puedo,

Porque por dentro estoy llorando. Muchos salen, aplauden, bailan...

Pero, ¿no tendríamos que llorar?

¿o reflexionar?

Muchos salen a aplaudir, pero, ¿no tendríamos que salir a llorar?

(C) 2020 por los autores; Esta obra está sujeta a la licencia de Reconocimiento 4.0

Internacional de Creative Commons. Para ver una copia de esta licencia, visite http://creativecommons.org/licenses/by-nc-nd/4.0/. 